Review / Derleme

\title{
Cell-free fetal DNA and RNA circulating in maternal blood: review, part I
}

\author{
Anne kanında serbest dolaşan hücre dışı fetal DNA ve RNA: derleme, \\ bölüm 1
}

Ali Çetin, MD $^{1}$

Department of Obstetrics and Gynecology, Cumhuriyet University School of Medicine, 58140 Sivas

\begin{abstract}
This review evaluates the scientific and clinical status of the use of circulating cell-free fetal nucleic acid technology for non-invasive prenatal diagnosis, a rapidly developing and dynamic field. After the landmark discovery of cell-free fetal DNA in maternal blood during pregnancy was made more than a decade ago, it was recognized that the cell-free fetal DNA represents only a small fraction of the total cell-free DNA in the maternal circulation during pregnancy. It is known that it can be reliably detected from 5 weeks gestation and is totally cleared within a few hours of birth. The promise of that breakthrough is now being realized as the technology is translated into clinical practice for the non-invasive prenatal diagnosis.
\end{abstract}

Keywords: Cell-free fetal nucleic acids, DNA, RNA, pregnancy, non-invasive prenatal diagnosis

Özet

Bu derleme hızlı gelişen ve dinamik bir alan olan non-invaziv prenatal tanı için dolaşımda bulunan hücre dışı fetal nükleik asitlerin kullanımının bilimsel ve klinik durumunu içerir. Gebelikte anne kanında hücre dışı fetal DNA'nın bulunmasının üzerinde on yıldan fazla süre geçtikten sonra, gebelikte anne kanında bulunan serbest DNA'nın küçük bir kısmını oluşturduğu görüldü. Gebeliğin beşinci haftasından sonra ölçülebilmektedir ve doğumdan kısa süre sonra kandan kaybolmaktadır. Bu ilerlemenin sayesinde non-invaziv prenatal tanı için bu teknoloji klinik pratiğe aktarılmaya çalışılmaktadır.

\footnotetext{
${ }^{1}$ Corresponding author:

Dr. Ali Çetin, Kadın Hastalıkları ve Doğum Anabilim Dalı, Cumhuriyet Üniversitesi Tıp

Fakültesi, TR-58140 Sivas

Email: dralicetin@yahoo.com
} 
Anahtar sözcükler: Hücre dışı fetal nükleik asitler, DNA, RNA, gebelik, non-invasiv prenatal tanı

\section{Introduction}

During pregnancy, the fetal and maternal circulations are separated by the placental membrane. In contrast to popular belief that the placenta forms an impermeable barrier between mother and child; however, a variety of evidence has pointed towards the incompleteness of this barrier to cellular trafficking. There is bidirectional traffic between the fetus and the mother during pregnancy (Lo et al., 1996). Multiple studies have shown that both intact fetal cells and cell-free fetal nucleic acids (cffNA) cross the placenta and circulate in the maternal bloodstream (Wright \& Burton, 2009).

\section{Fetal Nucleated Cells}

Universal presence of fetal cells in maternal blood is now accepted, but their occurrence is rare and requires complex enrichment and identification strategies (Bischoff et al., 2005). There exist one to six fetal cells per milliliter of blood from normal pregnant women (Hamada et al., 1993; Krabchi et al., 2001). Intact fetal cells circulating in maternal blood present an attractive target for NIPD, particularly for the diagnosis of fetal sex and chromosomal abnormalities by simple karyotyping. However, the difficulty in successfully detecting such fetal cells in maternal blood has been a major obstacle to the routine application of this concept. Although the existence of fetal cells in maternal blood has been known for more than a century, isolation of intact fetal nucleated red blood cells for the purpose of prenatal diagnosis was not achieved until 1990 (Bianchi et al., 1990). Since then, studies related to the fetal cells from maternal blood have been extensively investigated (Wright \& Burton, 2009). Although certain fetal cells (specifically nucleated red blood cells) have a relatively short lifespan in maternal blood (Lurie \& Mamet, 2000), other fetal cell types can persist in the maternal circulation for decades following pregnancy (Bianchi et al., 1996), potentially causing false-positive results in subsequent pregnancies. The largest study concerning the use of fetal cells in maternal blood was that of the multicentre National Institute of Child Health and Development (NICHD) fetal cell study group. Of 2744 maternal samples (Bianchi et al., 2002), fetal male cells were correctly identified in $41.4 \%$ when the fetus was euploid $(n=$ 1292). Among confirmed aneuploidy cases, the detection rate was higher: $74.4 \%$. Although further improvement of existing enrichment and isolation protocols is warranted, progress remains hampered by both rarity of fetal cells and the lack of fetalspecific cell markers (Bischoff et al., 2005).

\section{Cell-free Fetal Nucleic Acids}

Therefore, although research into sophisticated cell sorting techniques is ongoing, the majority of recent research has focused on cffNA in the maternal blood (Wright \& Burton, 2009). cffNA can be detected in the maternal circulation during pregnancy form 
5 weeks gestation, and they are rapidly cleared form the circulation following birth (Wright \& Burton, 2009).

Nucleic acids (DNA and RNA) in plasma were first observed $>50$ years ago. In the early 1970s, increased quantities of DNA were verified in the plasma of cancer patients (Leon et al., 1977). Investigations into the size of these plasma DNA fragments from cancer patients has revealed that the majority show lengths in multiples of nucleosomal DNA, a characteristic of apoptotic DNA fragmentation (Giacona et al., 1998; Jahr et al., 2001).

\section{Fetal/placental-derived RNA in Maternal Plasma}

In plasma from cancer patients, RNA is also shown to be present (Kopreski et al., 1999). These molecules are likely packaged in apoptotic bodies and, hence, rendered more stable compared to 'free RNA' (Hasselmann et al., 2001). Thus, it is not surprising that stable fetal RNA is also present in maternal plasma (Poon et al., 2000). Ng et al. (2003) detected maternal plasma mRNA transcripts exclusively expressed from the placenta. Two placenta-expressed genes (human placental lactogen, hPL; $b$ subunit of hCG) were detected in each of 10 maternal samples. This study provides direct evidence that RNA is stable in whole blood prior to processing and clearance following delivery. Investigations involving another plasma-expressed gene, corticotrophin-releasing hormone (CRH), have shown increased CRH mRNA in plasma of women with pre-eclampsia $(n=12$; mean 1070 copies $/ \mathrm{ml}$ ) compared with normal gestational age-matched controls $(\mathrm{n}=10 ; 102$ copies/ml) (Ng et al., 2003).

\section{Cell-free Fetal DNA}

In 1997, Lo et al. (1997) were the first to show the presence of cell-free fetal DNA (cffDNA) in plasma of pregnant women. They amplified the $Y$ chromosome-specific SRY sequence with real-time PCR in women carrying a male fetus. The origin of the cffDNA has remained uncertain, although evidence suggests that the placenta is the most likely source. Transplacental traffic of fetal hemopoietic cells is a potential alternative, but the number of these cells in the maternal circulation is considered to be too small to account for all of the cffDNA released. Clinical studies have suggested a strong association between trophoblast degeneration and the release of cffDNA into the maternal circulation (Tjoa et al., 2009). Tjoa et al. (2009) demonstrated that apoptosis related to oxidative stress induced the release of cell-free DNA from cultured placental villi.

Using quantitative real-time PCR, surprisingly high mean concentrations $(6.2 \%$ of total plasma DNA) of fetal DNA were found in maternal plasma in early and late pregnancy (Lo et al., 1998b). Several reports have confirmed that gestational age correlates positively with amount of fetal DNA in plasma; thus, higher detection rates are reported with increased gestation (Bischoff et al., 2005). 


\section{Level of Cell-free Fetal DNA}

As expected, detection of relatively low levels of fetal DNA sequences (as compared to maternal DNA levels) is dependent on the sensitivity of the assay as well as the amount of target fetal sequences. Little is known about the parameters governing the level of cffDNA. Several reports have confirmed that gestational age correlates positively with amount of fetal DNA in plasma; thus, higher detection rates are reported with increased gestation (Bischoff et al., 2005). Lo et al. (1998b) reported fetal concentrations to be low in the first trimester, rising in the second and third trimester. Ariga et al. (2001) combined real-time kinetic PCR with liquid oligomer hybridization with 32P-labelled probes to quantify $Y$ chromosome-specific sequences throughout pregnancy. In 20 women confirmed to have a male fetus and followed from the first to third trimester, fetal DNA concentrations increased from 10.1 to 130.5 copies per $0.5 \mathrm{ml}$ maternal plasma. Rijnders et al. (2003) studied pregnant women after assisted reproduction and reported detection of fetal DNA as early as 5 weeks and 2 days gestation in one of two patients; however, detection reached $100 \%$ by 9 weeks gestation.

During the last 8 weeks of pregnancy there is a sharp increase of fetal DNA in maternal plasma (Lo et al., 1998b). This might be related to gradual breakdown of the maternalfetal interface/placental barrier (Bianchi, 2000). To address this, Chan et al. (2003) performed serial analysis of fetal DNA concentrations in late pregnancy, showing a positive correlation with gestational age in the third trimester. During the late third trimester, they observed a mean increase of $29.3 \%$ of fetal DNA each week. Thus, they provide normative values for comparative studies involving pregnancy related pathological conditions such as preterm labor and preeclampsia (Bischoff et al., 2005).

The clearance of cffDNA from maternal plasma after delivery appears to occur in a rapid manner. The rate of clearance will also provide information as to the applicability of cffDNA measurement in the study of the dynamic processes involved in the handling of circulating DNA during pregnancy. The notable differences between fetal cell and cellfree DNA clearance suggest that the predominant cell populations involved may be distinct. For example, it is possible that the trophoblasts may be the predominant cell population involved in the liberation of fetal DNA into the cell-free fractions. Fetal erythroblasts, on the other hand, have been postulated to be the predominant fetal cell population found in maternal blood. By the use of cell sorting and sensitive PCR assays, fetal hematopoietic progenitor cells have been shown to persist in some women, even decades after delivery. The latter phenomenon has been associated with certain autoimmune disorders.

DYS19, DYS385 and DYS392 can be used as the Y chromosome-specific STR by using the following primers:

DYS19-F5'-CTATGAGTTTCTGTTATAGT3';

R5'-ATGGCATGTAGTGAGGACA3', 
DYS392-F5'-TCATTAATCTAGCTTTTAAAAACAA3';

R5' -AGACCCAGTTGATGCAATGT 3'

DYS385 - F5 '- AGCATGGGTGACAGAGCTA 3',

R5'-GGGATGCTAGGTAAAGCTG3'.

The amplification sensitivity of Y specific STR, DYS19 was $100 \%(22 / 22)$ in the male fetal DNA samples. The incidence of other STRs, i.e. DYS385 and DYS392 were 91\% (20/22) each (Nair et al, 2007).

\section{Use of Cell-free Fetal Nucleic Acids in Non-invasive Prenatal Diagnosis}

Traditional methods of prenatal diagnosis of genetic disorders use materials obtained by amniocentesis or chorionic villus sampling, invasive procedures that carry a small but clear risk of miscarriage (ACOG Practice Bulletin No. 88, 2007). Maternal serum analyte screening and ultrasound can identify individuals at risk for fetal aneuploidy (predominantly trisomy 21), but like other non-invasive screening methods, they are hampered by non-optimal sensitivities and high false-positive (procedure) rates (Bischoff et al., 2005). The discovery of cffNA in the plasma of pregnant mothers has led to the development of several NIPD techniques in the past decade. cffDNA in the maternal blood has been shown to help predict some sex-linked diseases and fetal hemolytic disease resulting from $\mathrm{Rh}$ blood group incompatibility. With use of cffDNA, non-invasive prenatal diagnosis (NIPD) of several conditions has been achieved, including fetal rhesus D status (Lo et al., 1998a), myotonic dystrophy (Amicucci et al., 2000), achondroplasia (Saito et al., 2000), and certain chromosomal translocations (Chen et al., 2000; Chen et al., 2001). cffNA circulating in maternal blood can be used for the early NIPD of an increasing number of genetic conditions, both for pregnancy management and to aid reproductive decision-making (Hall et al., 2010).

However, it is important to note that in all of the above situations, investigators have been restricted to detecting genes or mutations that the fetus has inherited from the father, which are genetically distinguishable from the DNA sequences of the mother. Robust detection and quantification have been achieved when the fetal DNA sequence of interest does not have a maternal counterpart (e.g., Y chromosomal DNA, RhD gene when the mother is RhD negative) by techniques such as real-time PCR. This limitation exists because fetal DNA in maternal plasma and serum is present in an excess background of maternal DNA (Bianchi, 1998). The possible introduction of fetal DNA in maternal plasma as a routine prenatal diagnostic tool has raised questions with regard to the need of a generic marker for circulating fetal DNA (Lo et al., 1998b; Avent et al., 2000). To date, most proposals for such a marker have focused on the use of genetic polymorphisms between the mother and fetus (Pertl et al., 2000; Tang et al., 1999). Poon et al. (2002) demonstrated that differential DNA methylation between fetus and mother can be used for detecting cffDNA in maternal plasma. They suggested that the feasibility of epigenetic markers for fetal DNA detection in maternal plasma may open 
up a new approach for the development of a gender- and polymorphism-independent fetal marker in maternal plasma.

The detection of fetal aneuploidy and autosomal recessive disorders with cffNA is particularly challenging because only a small portion of the cffNA in maternal plasma is derived from the fetus (Fan et al., 2010). Fan et al. (2008) demonstrated noninvasive detection of fetal aneuploidy by high-throughput shotgun sequencing of cffDNA, and their results were reproduced in two studies (Chiu et al., 2008; Chiu et al, 2010). Fan et al. (2010) demonstrated that paired-end-sequencing allows the direct measurement of the length distribution of cffDNA in maternal plasma, with single base resolution. They concluded that fetal DNA is shorter than maternal DNA and found that cffDNA had a dominant peak at approximately $162 \mathrm{bp}$ and a minor peak at approximately $340 \mathrm{bp}$.

\section{References}

1. American College of Obstetricians and Gynecologists. ACOG Practice Bulletin No. 88, December 2007. Invasive prenatal testing for aneuploidy. Obstet Gynecol. 2007 Dec;110(6):1459-67.

2. Amicucci P, Gennarelli M, Novelli G, Dallapiccola B. Prenatal diagnosis of myotonic dystrophy using fetal DNA obtained from maternal plasma. Clin Chem. 2000 Feb;46(2):301-2.

3. Ariga $H$, Ohto $H$, Busch MP, Imamura S, Watson R, Reed W, Lee TH. Kinetics of fetal cellular and cell-free DNA in the maternal circulation during and after pregnancy: implications for noninvasive prenatal diagnosis. Transfusion. 2001 Dec;41(12):1524-30.Avent ND, Finning KM, Martin PG, Soothill PW. Prenatal determination of fetal blood group status. Vox Sang. 2000;78 Suppl 2:155-62.

4. Bianchi DW, Flint AF, Pizzimenti MF, Knoll JH, Latt SA. Isolation of fetal DNA from nucleated erythrocytes in maternal blood. Proc Natl Acad Sci U S A. 1990 May;87(9):3279-83.

5. Bianchi DW, Simpson JL, Jackson LG, Elias S, Holzgreve W, Evans MI, Dukes KA, Sullivan LM, Klinger KW, Bischoff FZ, Hahn S, Johnson KL, Lewis D, Wapner RJ, de la Cruz F. Fetal gender and aneuploidy detection using fetal cells in maternal blood: analysis of NIFTY I data. National Institute of Child Health and Development Fetal Cell Isolation Study. Prenat Diagn. 2002 Jul;22(7):609-15.

6. Bianchi DW, Zickwolf GK, Weil GJ, Sylvester S, DeMaria MA. Male fetal progenitor cells persist in maternal blood for as long as 27 years postpartum. Proc Natl Acad Sci U S A. 1996 Jan 23;93(2):705-8.

7. Bianchi DW. Fetal cells in the mother: from genetic diagnosis to diseases associated with fetal cell microchimerism. Eur J Obstet Gynecol Reprod Biol. 2000 Sep;92(1):103-8.

8. Bianchi DW. Fetal DNA in maternal plasma: the plot thickens and the placental barrier thins. Am J Hum Genet. 1998 Apr;62(4):763-4.

9. Bischoff FZ, Lewis DE, Simpson JL. Cell-free fetal DNA in maternal blood: kinetics, source and structure. Hum Reprod Update. 2005 Jan-Feb;11(1):59-67. 
10. Chan LY, Leung TN, Chan KC, Tai HL, Lau TK, Wong EM, Lo YM. Serial analysis of fetal DNA concentrations in maternal plasma in late pregnancy. Clin Chem. 2003 Apr;49(4):678-80.

11. Chen CP, Chern SR, Wang W. Fetal DNA analyzed in plasma from a mother's three consecutive pregnancies to detect paternally inherited aneuploidy. Clin Chem. 2001 May;47(5):937-9.

12. Chen $C P$, Chern SR, Wang W. Fetal DNA in maternal plasma: the prenatal detection of a paternally inherited fetal aneuploidy. Prenat Diagn. 2000 Apr;20(4):355-7.

13. Chiu RW, Chan KC, Gao Y, Lau VY, Zheng W, Leung TY, Foo CH, Xie B, Tsui NB, Lun FM, Zee BC, Lau TK, Cantor CR, Lo YM. Noninvasive prenatal diagnosis of fetal chromosomal aneuploidy by massively parallel genomic sequencing of DNA in maternal plasma. Proc Natl Acad Sci U S A. 2008 Dec 23;105(51):20458-63. Epub 2008 Dec 10.

14. Chiu RW, Sun H, Akolekar R, Clouser C, Lee C, McKernan K, Zhou D, Nicolaides $\mathrm{KH}$, Lo YM. Maternal plasma DNA analysis with massively parallel sequencing by ligation for noninvasive prenatal diagnosis of trisomy 21. Clin Chem. 2010 Mar;56(3):459-63.

15. Fan HC, Blumenfeld YJ, Chitkara U, Hudgins L, Quake SR. Analysis of the size distributions of fetal and maternal cell-free DNA by paired-end sequencing. Clin Chem. 2010 Aug;56(8):1279-86.

16. Fan HC, Blumenfeld YJ, Chitkara U, Hudgins L, Quake SR. Noninvasive diagnosis of fetal aneuploidy by shotgun sequencing DNA from maternal blood. Proc Natl Acad Sci U S A. 2008 Oct 21;105(42):16266-71.

17. Giacona MB, Ruben GC, Iczkowski KA, Roos TB, Porter DM, Sorenson GD. Cellfree DNA in human blood plasma: length measurements in patients with pancreatic cancer and healthy controls. Pancreas. 1998 Jul;17(1):89-97.

18. Hall A, Bostanci A, Wright CF. Non-invasive prenatal diagnosis using cell-free fetal DNA technology: applications and implications. Public Health Genomics. 2010;13(4):246-55. Epub 2010 Apr 15.

19. Hamada $H$, Arinami $T$, Kubo $T$, Hamaguchi $H$, Iwasaki $H$. Fetal nucleated cells in maternal peripheral blood: frequency and relationship to gestational age. Hum Genet. 1993 Jun;91(5):427-32.

20. Hasselmann DO, Rappl G, Tilgen W, Reinhold U. Extracellular tyrosinase mRNA within apoptotic bodies is protected from degradation in human serum. Clin Chem. 2001 Aug;47(8):1488-9.

21. Jahr S, Hentze H, Englisch S, Hardt D, Fackelmayer FO, Hesch RD, Knippers R. DNA fragments in the blood plasma of cancer patients: quantitations and evidence for their origin from apoptotic and necrotic cells. Cancer Res. $2001 \mathrm{Feb}$ 15;61(4):1659-65.

22. Kopreski MS, Benko FA, Kwak LW, Gocke CD. Detection of tumor messenger RNA in the serum of patients with malignant melanoma. Clin Cancer Res. 1999 Aug;5(8):1961-5. 
23. Krabchi K, Gros-Louis F, Yan J, Bronsard M, Massé J, Forest JC, Drouin R. Quantification of all fetal nucleated cells in maternal blood between the 18th and 22nd weeks of pregnancy using molecular cytogenetic techniques. Clin Genet. 2001 Aug;60(2):145-50.

24. Leon SA, Shapiro B, Sklaroff DM, Yaros MJ. Free DNA in the serum of cancer patients and the effect of therapy. Cancer Res. 1977 Mar;37(3):646-50.

25. Lo YM, Corbetta N, Chamberlain PF, Rai V, Sargent IL, Redman CW, Wainscoat JS. Presence of fetal DNA in maternal plasma and serum. Lancet. 1997 Aug 16;350(9076):485-7.

26. Lo YM, Hjelm NM, Fidler C, Sargent IL, Murphy MF, Chamberlain PF, Poon PM, Redman CW, Wainscoat JS. Prenatal diagnosis of fetal RhD status by molecular analysis of maternal plasma. N Engl J Med. 1998a Dec 10;339(24):1734-8.

27. Lo YM, Lo ES, Watson N, Noakes L, Sargent IL, Thilaganathan B, Wainscoat IS. Two-way cell traffic between mother and fetus: biologic and clinical implications. Blood. 1996 Dec 1;88(11):4390-5.

28. Lo YM, Tein MS, Lau TK, Haines CJ, Leung TN, Poon PM, Wainscoat JS, Johnson PJ, Chang AM, Hjelm NM. Quantitative analysis of fetal DNA in maternal plasma and serum: implications for noninvasive prenatal diagnosis. Am J Hum Genet. 1998b Apr;62(4):768-75.

29. Lurie $S$, Mamet $Y$. Red blood cell survival and kinetics during pregnancy. Eur J Obstet Gynecol Reprod Biol. 2000 Dec;93(2):185-92.

30. Nair SP, Peter S, Pillay VV, Remya UM, Krishnaprasad R, Rajammal B. Detection of $Y$ STR markers of male fetal dna in maternal circulation. Indian J Hum Genet. 2007 February;13(2):69-72.

31. Ng EK, Tsui NB, Lau TK, Leung TN, Chiu RW, Panesar NS, Lit LC, Chan KW, Lo YM. mRNA of placental origin is readily detectable in maternal plasma. Proc Natl Acad Sci U S A. 2003 Apr 15;100(8):4748-53. Epub 2003 Mar 18.

32. Pertl B, Sekizawa A, Samura O, Orescovic I, Rahaim PT, Bianchi DW. Detection of male and female fetal DNA in maternal plasma by multiplex fluorescent polymerase chain reaction amplification of short tandem repeats. Hum Genet. 2000 Jan;106(1):45-9.

33. Poon LL, Leung TN, Lau TK, Chow KC, Lo YM. Differential DNA methylation between fetus and mother as a strategy for detecting fetal DNA in maternal plasma. Clin Chem. 2002 Jan;48(1):35-41.

34. Poon LL, Leung TN, Lau TK, Lo YM. Presence of fetal RNA in maternal plasma. Clin Chem. 2000 Nov;46(11):1832-4.

35. Rijnders RJ, Van Der Luijt RB, Peters ED, Goeree JK, Van Der Schoot CE, Ploos Van Amstel JK, Christiaens GC. Earliest gestational age for fetal sexing in cell-free maternal plasma. Prenat Diagn. 2003 Dec 30;23(13):1042-4.

36. Saito H, Sekizawa A, Morimoto T, Suzuki M, Yanaihara T. Prenatal DNA diagnosis of a single-gene disorder from maternal plasma. Lancet. 2000 Sep 30;356(9236):1170. 
37. Tang NL, Leung TN, Zhang J, Lau TK, Lo YM. Detection of fetal-derived paternally inherited X-chromosome polymorphisms in maternal plasma. Clin Chem. 1999 Nov;45(11):2033-5.

38. Tjoa ML, Cindrova-Davies T, Spasic-Boskovic O, Bianchi DW, Burton GJ. Trophoblastic oxidative stress and the release of cell-free feto-placental DNA. Am J Pathol. 2006 Aug;169(2):400-4.

39. Wright $\mathrm{CF}$, Burton $\mathrm{H}$. The use of cell-free fetal nucleic acids in maternal blood for non-invasive prenatal diagnosis. Hum Reprod Update. 2009 Jan-Feb;15(1):13951. 